\title{
FAKTOR YANG MEMPENGARUHI KETIDAKAMANAN KERJA (JOB INSECURITY) PADA PERAWAT DI RSUD DATU SANGGUL RANTAU DAN RSUD H. BADARUDDIN TANJUNG
}

\author{
Yuhansyah*, Yati Afiyanti**, Machli Riyadi*** \\ Email : tanyabagianpraktik@gmail.com \\ No HP: 0813-7912-7824
}

\begin{abstract}
Abstrak
Ketidakamanan kerja (job insecurity) merupakan suatu persepsi subyektif terhadap pentingnya aspek-aspek pekerjaan, ancaman terhadap aspek pekerjaan, pentingnya keseluruhan pekerjaan, ancaman terhadap keseluruhan pekerjaan dan ketidakberdayaan terhadap masalah pekerjaan. Faktor yang mempengaruhi ketidakamanan kerja diantaranya adalah karakteristik individu (usia, jenis kelamin, masa kerja, tingkat pendidikan, status perkawinan, pendapatan dan status kepegawaian). Penelitian ini bertujuan untuk mengetahui faktor yang mempengaruhi ketidakamanan kerja pada perawat di RSUD Datu Sanggul Rantau dan RSUD.H. Badaruddin Tanjung.
\end{abstract}

Metode penelitian ini adalah kuantitatif dengan desain penelitian cross sectional. Variabel independen faktor yang mepengaruhi dan variabel dependen ketidakamanan kerja. Jumlah sampel dalam penelitian ini sebanyak 256 responden terdiri dari 151 PNS dan 105 Non PNS. Instrument penelitian berupa kuesioner skala ketidakamnan kerja, uji statistik menggunakan regresi logistik ganda.Hasil penelitian ini menunjukkan ada faktor yang mempengaruhi ketidakamanan kerja yaitu masa kerja dan tingkat pendidikan dengan odds ratio 6,005. Hal ini dikarenakan perawat mengganggap perlindungan kerja, pembagian imbalan jasa pelayanan, kualitas pengawasan (supervisi) keperawatan dan pengembangan kompetensi sebagai salah satu aspek pekerjaan yang penting.

Kata Kunci : faktor yang mempengaruhi, ketidakamanan kerja (job inseceruty)

Daftar Rujukkan: 58 (1974-2016)

\section{abstract}

job insecurity is a subjective perception of the important aspects of the job, threats to aspects of the work, the overall importance of the work, the threat to the overall work and helplessness to the problem of work. The Factors that affecting job insecurity include individual characteristics (age, gender, years of work, education level, marital status, income and employment status). This study aims to determine the correlation between employment status with job insecurity and factors that affecting nurses in Datu SanggulRantauhospital and H. BadaruddinTanjung hospital.

The research method was quantitative with cross sectional design.The independent variable was employment status and the dependent variable was job insecurity. The number of samples in this study were 256 respondents consisted of 151 civil servants and 105 Non PNS. Research instrument was a questionnaire job insecurity scale, the statistical test used multiple logistic regression. factors that affecting the level of education by the odds ratio 6.005. This is because the nurse considersto safety in work, honorarium of service the quality of monitoring (supervision) nursing and competency development as one of the important aspects of the work.

Keywords: employment status, job insecurity,

Reference: 58 (1974-2016) 


\section{PENDAHULUAN}

Pelayanan kesehatan merupakan salah satu bentuk pelayanan jasa yang diberikan kepada individu, kelompok dan masyarakat dalam upaya pemenuhan kebutuan biologis, psikogis sosial dan spiritual salah satu tempat untuk memberikan pelayanan kesehatan adalah di rumah sakit. Menurut Undang-Undang Nomor 44 Tahun 2009 Tentang Rumah Sakit Pasal 1 angka 1 menyebutkan, Rumah Sakit adalah institusi pelayanan kesehatan yang menyelenggarakan pelayanan kesehatan perorangan secara paripurna yang menyediakan pelayanan rawat jalan, rawat inap, dan gawat darurat. Salah satu rumah sakit yang ada di Kalimantan Selatan adalah RSUD Datu Sanggul Rantau dan RSUD H. Badaruddin Tanjung.

Tenaga kesehatan yang bekerja di rumah sakit pada umumnya adalah perawat dan mempunyai status kepegawaian sebagai ASN yang terdiri dari PNS dan PPPK (Non PNS), menurut Undang-Undang Republik Indonesia Nomor 5 Tahun 2014 Tentang Aparatur Sipil Negara Pasal 7 angka 1 dan 2 menyebutkan, PNS merupakan Pegawai ASN yang diangkat sebagai pegawai tetap oleh Pejabat Pembina Kepegawaian dan memiliki nomor induk secara nasional. PPPK atau sering disebut Non PNS merupakan Pegawai ASN yang diangkat sebagai pegawai dengan perjanjian kerja oleh Pejabat Pembina Kepegawaian sesuai dengan kebutuhan Instansi Pemerintah dan ketentuan Undang-Undang.

Perawat di RSUD Datu Sanggul Rantau dan RSUD H. Badaruddin Tanjung bekerja untuk memberikan pelayanan kesehatan khususnya pelayanan keperawatan dalam rangka meningkatkan status kesehatan pasien perlu mendapatkan perlindungan hukum, pengembangan kompetensi. kesehatan dan keselamatan kerja, sehingga perawat akan merasa aman dan nyaman dalam melakukan pekerjaan

Salah satu kondisi keamanan kerja bagi perawat dalam memberikan pelayanan keperawatan adalah mengatasi ketidakamanan kerja (job insecurity). ketidakamanan kerja menurut Greenhalgh \& Rosenblatt (2010: 10) dalam Sulistyawati (2012) adalah sebagai kondisi ketidakberdayaan untuk mempertahankan kesinambungan yang diinginkan dalam kondisi kerja yang terancam. Ashford, Lee dan Bobko (1989) menyebutkan bahwa dimensi ketidakamanan kerja terdiri dari ancaman terhadap aspek-aspek pekerjaan, tingkat pentingnya ancaman terhadap aspek-aspek pekerjaan, ancaman terhadap keseluruhan pekerjaan, tingkat pentingnya ancaman terhadap keseluruhan pekerjaan, dan ketidakberdayaan.

Penelitian yang dilakukan oleh De Cuyper dan De White (2007) terhadap 477 pegawai tetap dan tidak tetap dari berbagai sektor pekerjaan di Belgia menunjukkan bahwa hasil hubungan antara ketidakamanan kerja dengan status kepegawaian (tetap dan tidak tetap) terbatas pada kepuasan kerja dan komitmen organisasi dimana pegawai tetap memiliki harapan yang lebih tinggi tentang keamanan kerja.

Hasil studi pendahuluan beberapa aspek pekerjaan masih belum optimal pelaksanaanya pembagian imbalan jasa pelayanan keperawatan dengan sistem sama rata diantara perawat, tidak adanya penilaian kinerja terhadap perawat kontrak dan belum adanya survie kepuasan kerja tenaga kesehatan dan karyawan di rumah sakit. sarana dan prasarana yang masih belum memadai khususnya fasilitas kebersihan cuci tangan untuk mengurangi resiko terjadinya infeksi akibat dari pekerjaan yang dilakukan.

Berdasarkan fenomena pada latar belakang di atas peneliti tertarik melakukan penelitian lebih lanjut kepada perawat yang bekerja di rumah sakit dengan status kepegawaian PNS dan Non PNS untuk mengetahui faktor yang mempengaruhi ketidakamanan kerja pada perawat di RSUD Datu Sanggul Rantau dan RSUD H. Badaruddin Tanjung.

Tujuan penelitian adalah mengetahui faktor yang mempengaruhi ketidakamanan kerja. Secara khusus, penelitian ini bertujuan untuk mengetahui, mengetahui faktor yang mempengaruhi ketidakamanan kerja.

\section{METODE PENELITIAN}

Penelitian ini menggunakan pendekatan kuantitatif dengan rancangan penelitian cross sectional, yaitu jenis penelitian yang menekankan waktu pengukuran/observasi data variabel indevenden dan dependen serta variabel moderator hanya satu kali pada satu saat. (Nursalam, 2013:163).

Sampel penelitian ini yaitu 256 perawat pelaksana di RSUD Datu Sanggul Rantau dan RSUD H. Badaruddin Tanjung. Pengambilan data dilakukan pada bulan November 2017 sampai dengan bulan Januari 2018. 
Analisis data yang digunakan dalam penelitian ini mengunakan analisis univariat bertujuan untuk mendeskripsikan masing-masing variabel dan analisis multivariat bertujuan untuk menguji hipotesis penelitian dan dilakukan untuk mengetahui faktor yang mempengaruhi ketidakamanan kerja.

Uji statistik yang dilakukan menggunakan uji Uji regresi logistik ganda digunakan untuk mencari faktor yang mempengaruhi ketidakamanan kerja.

\section{HASIL PENELITIAN}

\section{A. Univariat}

1) Karakteristik responden

Tabel 1.1

Distribusi frekuensi berdasarkan Karakteristik responden

\begin{tabular}{|c|c|c|}
\hline \\
\hline \multirow{2}{*}{\multicolumn{3}{|c|}{$\begin{array}{l}\text { Karakteristik } \\
\text { Usia }\end{array}$}} \\
\hline & & \\
\hline $15-24$ tahun & 16 & 6,3 \\
\hline 25-44 tahun & 231 & 90,2 \\
\hline $45-65$ tahun & 9 & 3,5 \\
\hline Total & 256 & 100 \\
\hline
\end{tabular}

\begin{tabular}{|c|c|c|}
\hline \multirow{2}{*}{\multicolumn{3}{|c|}{ Jenis kelamin }} \\
\hline & & \\
\hline Laki-laki & 101 & 41 \\
\hline Perempuan & 151 & 59 \\
\hline Total & 256 & 100 \\
\hline \multicolumn{3}{|l|}{ Masa kerja } \\
\hline$<2$ tahun & 38 & 14,9 \\
\hline 2-10 tahun & 153 & 59,7 \\
\hline$>10$ tahun & 65 & 25,4 \\
\hline Total & 58 & 100.0 \\
\hline \multicolumn{3}{|c|}{ Tingkat pendidikan } \\
\hline SPK & 6 & 2,4 \\
\hline DIII & 186 & 72,7 \\
\hline $\mathrm{S} 1$ & 22 & 8,5 \\
\hline Ners & 42 & 16,4 \\
\hline Total & 256 & 100.0 \\
\hline \multicolumn{3}{|c|}{ Status perkawinan } \\
\hline Belum kawin & 31 & 12,2 \\
\hline Kawin & 225 & 87,8 \\
\hline Total & 256 & 100 \\
\hline \multicolumn{3}{|l|}{ Pendapatan } \\
\hline$>$ Rp. 3.500 .000 & 88 & 34,4 \\
\hline$<$ Rp. 3.500 .000 & 168 & 65,6 \\
\hline Total & 256 & 100 \\
\hline \multicolumn{3}{|c|}{ Status kepegawaian } \\
\hline PNS & 105 & 41 \\
\hline Non PNS & 151 & 59 \\
\hline Total & 256 & 100 \\
\hline \multicolumn{3}{|c|}{ Ketidakamanan kerja } \\
\hline Rendah & 129 & 50,3 \\
\hline Tinggi & 127 & 49,7 \\
\hline Total & 256 & 100 \\
\hline
\end{tabular}

Karakteristik responden dan tingkat ketidakamanan kerja responden di RSUD Datu Sanggul Rantau paling banyak adalah usia 25-44 tahun sebanyak 231 orang $(90,2 \%)$, jenis kelamin perempuan sebanyak 151 orang (51\%), masa kerja 2-10 tahun sebanyak 153 orang (59,7\%), tingkat pendidikan Diploma III (D III) sebanyak 186 orang $(72,7 \%)$, status kawin $225(87,8 \%)$, pendapatan < Rp. 3.500 .000 sebanyak 168 orang $(65,6)$, status kepegawaian PNS sebanyak 151 orang (59\%) dan tingkat ketidakaman kerja rendah sebanyak 129 orang $(50,3 \%)$. 
Tabel 1.4

Analisis Regresi Logistik Ganda

\begin{tabular}{lcccccccc}
\hline \multicolumn{1}{c}{ Variabel } & \multirow{R}{*}{ S.E. } & Wald & df & $\boldsymbol{\rho}$ & OR & \multicolumn{2}{c}{ IK95\% } \\
& & & & & & & Min & Max \\
\hline Masa kerja & & & 9,268 & 2 & 0,010 & & & \\
>10 Tahun & & & & & & & \\
2-10 Tahun & $-0,849$ & 0,311 & 7,454 & 1 & 0,006 & 0,428 & 0,232 & 0,787 \\
< 2 Tahun & $-0,106$ & 0,428 & 0,062 & 1 & 0,804 & 0,899 & 0,389 & 2,080 \\
\hline Tingkat & & & & & & & & \\
pendidikan & & & 7,694 & 3 & 0,053 & & & \\
Ners & & & & & & & \\
S1 & $-1,078$ & 0,554 & 3,792 & 1 & 0,051 & 0,340 & 0,115 & 1,007 \\
D III & $-0,705$ & 0,361 & 3,803 & 1 & 0,051 & 0,494 & 0,243 & 1,004 \\
SPK & $-2,506$ & 1,160 & 4,666 & 1 & 0,031 & 0,082 & 0,008 & 0,793 \\
Konstanta & 1,168 & 0,405 & 8,308 & 1 & 0,004 & 3,217 & & \\
\hline
\end{tabular}

Hasil analisis regresi logistik ganda menunjukkan bahwa, faktor yang berhubungan bermakna dengan ketidamanan kerja adalah masa kerja dan tingkat pendidikan seperti ancaman kehilangan pekerjaan, kualitas pengawasan dan pengembangan kompetensi

Hasil analisis regresi logistik ganda masa kerja diketahui nilai $\rho$ hitung sebesar 0,010 . Nilai $\rho$ hitung ini lebih kecil jika dibandingkan dengan nilai $\alpha(0,010<0,05)$ dengan demikian dapat dikatakan bahwa masa kerja berhubungan bermakna dengan ketidakamanan kerja.

Nilai Odss Ratio (OR) masa kerja 2-10 tahun diketahui sebesar 0,428 dibanding masa kerja > 10 tahun dengan demikian dapat disimpulkan bahwa peluang masa kerja 2-10 tahun mengalami ketidakamanan kerja adalah 0,42 kali peluang masa kerja > 10 tahun mengalami ketidakamanan kerja.

Nilai Odds Ratio (OR) masa kerja $<2$ tahun diketahui sebesar 0,899 dibanding masa kerja $>10$ tahun dengan demikian dapat disimpulkan bahwa peluang masa kerja $<2$ tahun mengalami ketidakamanan kerja adalah 0,89 kali peluang masa kerja > 10 tahun mengalami ketidakamanan kerja. Nilai Odds Ratio (OR) tingkat pendidikan SPK diketahui sebesar 0,082 dibanding tingkat pendidikan ners dengan demikian dapat disimpulkan bahwa peluang responden dengan tingkat pendidikan SPK mengalami ketidakamanan kerja adalah 0,08 kali peluang tingkat pendidikan ners mengalami ketidakamanan kerja.

Nilai Odds Ratio (OR) tingkat pendidikan D III diketahui sebesar 0,494 dibanding tingkat pendidikan ners dengan demikian dapat disimpulkan bahwa peluang responden dengan tingkat pendidikan D III mengalami ketidakamanan kerja adalah 0,49 kali peluang tingkat pendidikan ners mengalami ketidakamanan kerja.

Nilai Odds Ratio (OR) tingkat pendidikan S1 diketahui sebesar 0,340 dibanding tingkat pendidikan ners dengan demikian dapat disimpulkan bahwa peluang responden dengan tingkat pendidikan S1 mengalami ketidakamanan kerja adalah 0,34 kali peluang tingkat pendidikan ners mengalami ketidakamanan kerja.

\section{PEMBAHASAN}

Faktor yang mempengaruhi ketidakamanan kerja

Hasil analisis menunjukkan bahwa faktor masa kerja berhubungan bermakna dengan ketidakamanan kerja. Pegawai masa kerja 0-10 tahun berpeluang mengalami ketidakamanan kerja, khususnya bagi pegawai dengan status kontrak atau sering dikenal dengan pegawai Non PNS ketidakamanan kerja yang dirasakan karena berisiko mengalami kehilangan pekerjaan. Item kuesioner menunjukkan bahwa yang memiliki tingkat ketidakamanan kerja tinggi meanggap 
Kehilangan pekerjaan pada pegawai PNS dapat disebabkan pindah kerja ke instansi lain, penisun dini atau atas permintaan sendiri sedangkan pada pegawai Non PNS dapat disebabkan karena jangka waktu perjanjian kerja berakhir, atas permintaan sendiri, melakukan pelanggaran disiplin tingkat berat, tidak memenuhi target kinerja yang telah disepakati, dihukum penjara dengan ancaman hukuman minimal dua tahun penjara dan menjadi anggota partai politik. Peraturan perjanjian kerja

diamanatkan dalam Undang-Undang Nomor 13 Tahun 2003 Tentang Ketenagakerjaan dan Undang-Undang Nomor 5 Tahun 2014 Tentang ASN.

Ketika ancaman kehilangan pekerjaan dirasakan semakin tinggi oleh seorang pegawai maka tingkat ketidakamanan kerja juga akan meningkat dan dapat memberikan pengaruh bagi orang-orang yang ada disekitarnya termasuk organisasi tempat dia bekerja serta bagi pekerjaannya sendiri.

Hasil analisis menunjukkan bahwa faktor tingkat pendidikan berhubungan bermakna terhadap ketidakamanan kerja. Perawat dengan tingkat pendidikan berisiko mengalami ketidakamanan kerja dikarenakan adanya perbedaan pengetahuan yang diterima ketika seorang perawat masih menempuh masa pendidikan di akademi keperawatan dan sekolah tinggi keperawatan.

Hasil penelitian Lee, et al (2013) menunjukkan bahwa pegawai dengan tingkat ketidakamanan kerja yang tinggi lebih banyak dialami oleh pegawai dengan tingkat pendidikan Sekolah Menengah Atas (SMA) dibandingkan pegawai dengan tingkat pendidikan yang lebih tinggi.

Semakin tinggi tingkat pendidikan individu maka resiko mengalami ketidakamanan kerja kemungkinan akan semakin rendah, hal ini dapat disebabkan karena perbedaan tentang penerimaaan gaji dan tunjangan yang berbeda antara pegawai dengan tingkat pendidikan yang lebih tinggi dibandingkan dengan pegawai lainnya yang memiliki tingkat pendidikan satu tingkat dibawahnya. Penelitian yang dilakukan oleh Frese, (1985); Kinnunen et al, (1999) dalam Sverke (2006) menyatakan individu yang mempunyai tingkat pendidikan dan gaji yang rendah lebih rentan mengalami ancaman kehilangan pekerjaan.

Pekerja dengan status rendah juga sering dikaitkan dengan pegawai dengan tingkat pendidikan yang rendah, studi menunjukkan bahwa pegawai kerah biru (pegawai yang dibayar perjam) melaporkan tingkat ketidakamanan kerja yang tinggi dibandingkan dengan kategori pegawai lainnya. (Naswall \& De Witte, 2003 dalam Sverke et al, 2006).

Item kuesioner menunjukkan bahwa pegawai dengan tingkat pendidikan SPK, D III, S1 dan Ners meanggap kualitas pengawasan yang diberikan dan tugas yang dikerjakan setiap harinya merupakan sesuatu yang penting dalam kehidupan kerja. Pengawasan atau superivisi merupakan sesuatu yang penting hal ini dilakukan untuk memberikan umpan balik terhadap suatu tindakan pekerjaan yang telah dilakukan dimana pengawasan yang baik dapat meningkatkan kualitas pelayanan keperawatan dan menjalin hubungan yang baik antara perawat.

Di RSUD Datu Sanggul Rantau dan RSUD H. Badaruddin Tanjung Pelaksanaan Supervisi masih belum berjalan optimal. Supervisor merupakan kegiatan pelayanan profesional untuk membantu atau membimbing pihak yang dilayani. Supervisi keperawatan yang baik pada pelayanan keperawatan dapat meningkatkan kepuasan kerja. Hasil penelitian yang dilakukan oleh Harikadua (2014) menunjukkan bahwa pelaksanaan supervisi keperawatan di RSUP Prof. Dr. R. D. Kandou Manado menunjukkan bahwa ada hubungan antara supervisi keperawatan dengan kepuasan kerja di mana ketika supervisi dilakukan dengan baik maka kepuasan kerja juga akan meningkat.

Kepuasan kerja yang baik dapat mengurangi ketidakamanan kerja pada perawat, hasil rekapitulasi kuesioner menunjukkan bahwa perawat dengan tingkat ketidakamanan kerja yang tinggi meanggap bahwa dampak atas pekerjaan yang dilakukan memberikan dampak yang bearti atau baik bagi orang lain merupakan sesuatu hal yang penting dimana hasil pekerjaan yang baik dapat memberikan kepuasan tersendiri bagi perawat.

Ketika ketidakpuasan kerja akibat pekerjaan dirasakan oleh seorang perawat maka akan berisiko menimbulkan rasa ketidakamanan kerja saat beraktifitas dalam pekerjaan sehari-hari. Hal ini sejalan dengan 
penelitian yang dilakukan oleh Antonia (2016) menunjukkan bahwa ada pengaruh yang negatif antara ketidakamanan kerja dengan kepuasan kerja hal ini dapat diartikan semakin tinggi rasa ketidakamanan kerja maka akan semakin rendah kepuasan kerja yang didapatkan.

Tingkat pendidikan merupakan suatu yang dapat menyebabkan ketidakamanan kerja maka organisasi perlu melakukan pengembangan kompetensi sumber daya manusia dengan cara meningkatkan tingkat pendidikan melalu jalur formal (sekolah) atau non formal (pelatihan, seminar dan workshop), karena dengan memberikan pengembangan kompetensi maka akan meningkatkan tingkat pengetahuan sehingga organisasi dapat mengurangi rasa ketidakamanan kerja yang dirasakan oleh seorang perawat.

Item kuesioner menunjukkan bahwa untuk pegawai dengan tingkat ketidakamanan kerja tinggi baik itu dengan pendidikan SPK, D III, S1 dan Ners menjawab pegembangan kompetensi merupakan suatu hal yang penting dalam kehidupan kerja.

Pengembangan kompetensi seorang pegawai bertujuan untuk meningkatkan tingkat pengetahuan semakin baik tingkat pengetahuan pegawai maka akan semakin mudah pegawai untuk meningkatkan jenjang karirnya ketika berada dalam suatu organisasi.

Pada profesi perawat untuk meningkatkan kompetensi dilakukanlah sistem jenjang karir perawat dengan tujuan untuk memberikan penghargaan atas level kompetensi yang sudah didapatkan. Di RSUD Datu Sanggul Rantau dan RSUD H. Badaruddin Tanjung sistem jenjang karir perawat masih belum berjalan dengan optimal. Ketika sistem jenjang karir ini tidak berjalan dengan baik maka pemberian pelayanan keperawatan tidak dapat berjalan dengan maksimal dan berisiko memberikan rasa ketidakamanan saat bekerja karena perawat tidak mengetahui sebatas mana kompetensinya ketika melaksanakan suatu pekerjaan.

Dalam sistem jenjang karir terdapat tiga aspek yang berhubungan yaitu kinerja, orientasi profesional, dan kepribadian perawat. (Depkes RI, 2006). Jenjang karir yang dilaksanakan dengan baik dapat meningkatkan kinerja kerja seorang perawat dan mengurangi dampak dari ketidakamanan kerja. Penelitian yang dilakukan oleh Nugraha (2010) menunjukkan bahwa semakin tinggi tingkat ketidakamanan kerja maka akan semakin rendah kinerja kerja seorang pegawai.

Hasil analisis menunjukkan bahwa pada penelitian ini faktor masa kerja, usia, jenis kelamin, pendapatan, status perkawinan dan status kepegawaian bukan faktor yang mempengaruhi ketidakamanan kerja pada perawat di RSUD Datu Sanggul Rantau dan RSUD H. Badaruddin Tanjung hal ini dikarenakan saat memberikan pelayanan keperawatan kepada masyarakat di pelayanan kesehatan seorang perawat terikat dengan kode etik keperawatan yaitu tidak terpengaruh oleh pertimbangan kebangsaan, kesukuan, warna kulit, umur, jenis kelamin, aliran politik dan agama yng dianut serta kedudukan sosial (PPNI, 1989) sehingga hal ini juga berlaku kepada perawat pemberi pelayanan keperawatan dimana dalam memberikan pelayanan seorang perawat harus bisa mengesampingkan usia, jenis kelamin, masa kerja, status perkawinan, pendapatan dan status kepegawaian dengan tujuan utama adalah memberikan asuhan keperawatan demi keselamatan pasien.

Adanya kesamaan kewajiban perawat saat berpraktik dipelayanan kesehatan yang membuat faktor usia, jenis kelamin, masa kerja, status perkawinan, pendapatan dan status kepegawaian tidak mempengaruhi terhadap ketidakamanan kerja seperti yang diamanatkan oleh Undang-Undang Nomor 38 Tahun 2014 Pasal 37 Huruf a sampai g diantaranya huruf $\mathrm{b}$ dan $\mathrm{c}$ menyebutkan, perawat dalam berpraktik berkewajiban memberikan pelayanan keperawatan sesuai kode etik, standar pelayanan keperawatan, standar profesi, standar prosedur operasional, dan ketentuan perundang-undangan. Merujuk klien yang tidak dapat ditangani kepada perawat atau tenaga kesehatan lain yang lebih tepat sesuai dengan lingkup dan tingkat kompetensinya.

Berbeda dengan jenis-jenis perusahaan atau instansi yang tidak bergerak dalam pelayanan kesehatan seperti rumah sakit, pegawai yang mengalami ketidakamanan kerja dapat dipengaruhi oleh usia, jenis kelamin, masa kerja, status perkawinan, pendapatan dan status kepegawaian hal ini dikarenankan adanya perbedaan antara satu perusahan atau instansi lain tentang tujuan organisasi, hak dan kewajiban kerja serta aturan yang berlaku.

\section{KESIMPULAN}


Faktor tingkat pendidikan merupakan faktor yang mempengaruhi ketidakamanan kerja pada perawat di RSUD Datu Sanggul Rantau dan RSUD H. Badaruddin Tanjung dengan nilai Odds Ratio (OR) sebesar 6,005 .

\section{SARAN}

\section{Rumah Sakit}

Manajemen rumah sakit khususnya bidang keperawatan disarankan untuk meningkatkan fasilitas perlindungan kerja bagi pegawai seperti fasilitas kebersihan tangan. Melakukan penilaian kinerja dan kepuasan kerja pegawai serta menyusun formula pembagian jasa berdasarkan kinerja.

\section{Institusi Pendidikan}

Institusi pendidikan meningkatan kualitas pembelajaran khususnya mata kuliah manajemen keperawatan dan manajemen sumber daya manusia seperti penilaian kinerja dan penyusunan formulas pembagian jasa.

\section{Peneliti selanjutnya}

Peneliti selanjutnya dapat melakukan penelitian dengan metode kualitatif untuk mengkaji lebih dalam tentang ketidakamanan kerja terkait permasalahan pembagian imbalan jasa dan perlindungan kerja serta menjadi sumber rujukan dalam peneltian yang akan datang.

\section{Organisasi Profesi}

Organisasi profesi perawat (PPNI) diharapakan dapat menyusun standar gaji perawat di daerah dalam rangka meningkatkan kesejahteraan perawat.

\section{Perawat}

Perawat yang bekerja di rumah sakit diharapakan penelitian ini dapat dijadikan sebagai bahan bacaan dan informasi dalam melindungi diri dari ketidakamanan kerja serta segera melaporkan apabila mengalami masalah ketidakamanan kerja.

\section{DAFTAR RUJUKAN}

Artha., P.I. 2013. Hubungan Locus Of Control Dan Job Insecurity Pada Pekerja Kontrak Bank X Di Solo. Universitas Indonesia. Tersedia dalam: <lib.ui.ac.id.> (diakses 18 Agustus 2017).

Ashford, S.J., Lee, C., \& Bobko, P. 1989. Content, Causes, And Consequences Of Job Insecurity: A Theory-Based Measure And Substantive Test. Available from: <http://www.jstor.org>. (diakses 7 September 2017).

Dahlan, M.S. 2016. Analisis Multivariat Regresi Logistik Seri 9 Cetakan Ke 2. Jakarta: Epidemiologi Indonesia

Dahlan, M.S. 2014. Statistik Untuk Kedokteran Dan Kesehatan. Jakarta: Epidemiologi Indonesia

De Cuyper, N., \& De Witte., H. 2005. Job insecurity: mediator or moderator Of the relationship between type of Contract and various outcomes? ${ }^{1}$. Available from: $<$ http://www.sajip.co.za>. (diakses 9 September 2017).

De Cuyper, N., \& De Witte., H. 2007. Job Insecurity In Temporary Versus Permanent Workers: Associattions With Attitudes, Well-Being, And Behavior. Available from: https://www.research gate. net/publication/247511172 (diakses 21 Agustus 2017).

Departemen Kesehatan RI. 2002. Pedoman Peraturan Internal Rumah Sakit (Hospital By Law). Jakarta: Departemen Kesehatan RI Direktorat Jendral Pelayanan Medik 
Departemen Kesehatan RI. 2002. Pedoman Pencegahan dan Pengendalian Infeksi di Rumah Sakit dan Fasilitas Kesehatan Lainnya Cetakan Kedua. Jakarta: Departemen Kesehatan RI.

Dinas Kesehatan Kabupaten Tabalong. 2015. Profil Kesehatan Kabupaten Tabalong. Tabalong: Dinas Kesehatan Kabupaten Tabalong.

Dhamayanti, Ratna. 2006. Pengaruh Konflik Keluarga-Pekerjaan dan Tekananan Pekerjaan Terhadap Kepuasan Kerja Karyawan Wanita Studi pada Nusantara Tour dan Travel Kantor Cabang dan Kantor Pusat Semarang. Universitas Diponegoro Tersedia di < http://ejournal.undip.ac.id/index.php/smo> (diakses 23 September 2017).

DPP PPNI. 1989. Kode Etik Keperawatan. Jakarta. Tersedia dalam <https://inna-ppni.or.id/> (diakses 15 Januari 2018).

DPD PPNI Provinsi Jawa Tengah yang telah membuat Surat Keputusan Nomor : 028/DPW.PPNI/SK/K.S /IV/2016 Tentang Pedoman Gaji Perawat di Institusi Pelayanan Kesehatan dan Pendidikan Jawa Tengah Tahun 2016. Tersedia dalam $<$ https://ppnijateng.org/> (diakses 15 Januari 2018).

Dwi, Irma Kurniawati. 2014. Masa Kerja Dengan Job Engagement Pada Karyawan. Universitas Muhammadiyah Malang Tersedia di <ttp:// ejournal.umm.ac.id/index.php/jipt/article/view/2005 (diakses 15 Januari 2018).

European Foundation for the Improvement of Living and Working Conditions. 2010. Changes over time - First findings from the fifth European Working Conditions Survey. Available from: < ec.europa.eu>. (diakses 15 Januari 2018).

Harikadua, Alfrian. Herman Warouw \& Rivelino S. Hamel. 2014. Hubungan Supervisi Keperawatan dengan Kepuasan Kerja Perawat Pelaksana di Irina C BLU RSUP Prof. Dr. R. D. Kandou Manado. Tersedia dalam <https://media.neliti.com> (diakses 15 Januari 2018).

Hartley, J., Jacobson, D., Klandermans, B., \& van Vuuren, T. 1991. Job insecurity: Coping with jobs at risk. London: Sage.

Hungu. 2007. Demografi Kesehatan Indonesia. Jakarta: Grasindo

Kamus Besar Bahasa Indonesia (KBBI) Online. (2017). Tersedia dalam: <https://.kbbi.web.id> (diakses 22 September 2017).

Kementrian Kesehatan RI. 2014. Profil Kesehatan Kesehatan RI (Visi dan Misi). Jakarta: Kementrian Kesehatan RI. Tersedia di <www.kemkes.go.id> (diakses 23 September 2017).

Kementrian Kesehatan RI. (2016). Profil Kementrian Kesehatan 2015. Jakarta: Kementrian Kesehatan RI. Tersedia di <www.kemkes.go.id> (diakses 23 September 2017).

Kementerian Pendidikan dan Kebudayaan RI. 2016. Pedoman Umum Ejaan Bahasa Indonesia. Jakarta: Badan Pengembangan dan Pembinaan Bahasa. <www.badanbahasa.kemendikbud.go.id> (diakses 19 November 2017). 
Kitab Undang-Undang Hukum Pidana Tersedia dalam: <kejari-sanggau.go.id.> (diakses 5 Oktober 2017).

Lee, et al. 2013. Association between work-related health problems and job insecurity in permanent and temporary employees. Annals of Occupational and Evironmental Medicine. Available from: <www.ncbi.nlm.nih.gov>. (diakses 20 November 2017).

Madona., A.C. 2016. Pengaruh Job Insecurity Dan Employee Empowerment Terhadap Job Satisfaction Dalam Meningkatkan Employee Performance Pada Karyawan Service Contract Union Nations Development Programme (UNDP) Indonesia. Universitas Indonesia. Tersedia dalam: <lib.ui.ac.id.> (diakses 18 Agustus 2017).

Maulana., S. 2012. Hubungan Antara Job Insecurity Dan Work Engagement Pada Dosen NonPegawai Negeri Sipil (Non-PNS) Universitas Indonesia. Universitas Indonesia Tersedia dalam: <lib.ui.ac.id.> (diakses 18 Agustus 2017).

Marquis, B.L., \& Huston, C.J. 2013. Kepemimpinan Dan Manajemen Keperawatan Edisi 4. Jakarta: EGC

Misbahuddin., \& Hasan, I. 2013. Analisis Data Penelitian dengan Statistik Ed ke 2. Jakarta: Bumi Aksara.

Musyaddad, Kholid. Prinsip-Prinsip Manajemen Sumber Daya Manusia dalam Persfektif Islam. Tersedia dalam <https://media.neliti.com> (diakses 15 Januari 2018).

Nugraha, Adhian. 2010. Analisis Pengaruh Ketidakamanan Kerja dan Kepuasan Kompensasi Terhadap Kinerja Karyawan. Semarang: Universitas Diponegoro. Tersedia dalam <http://ejournal-s1.undip.ac.id/index.> (diakses 15 Januari 2018).

Nursalam. (2013). Metodologi Penelitian Ilmu Keperawatan Pendekatan Praktis. Jakarta: Salemba Medika.

Nursalam. (2015). Manajemen Keperawatan Aplikasi dalam Praktik Keperawatan Profesional. Jakarta: Salemba Medika.

Notoatmodjo, S. 2010. Metode Penelitian Kesehatan. Jakarta: Rineka Cipta.

Paul, L.P \& Brijball, S.P. 2012. Employee Susceptibility To Experiencing Job Insecurity. Sajems NS 15 (2012) No.1. Available from: <https:sajems.org>. (diakses 21 Agustus 2017).

Raihan. 2011. Persepsi dan Pengalaman Perawat Pelaksana Terhadap Pelaksanaan Rotas Kerja di Rumah Sakit Umum Daerah Dokter Soedarso Pontianak. Tersedia dalam: <lib.ui.ac.id.> (diakses 15 Januari 2018).

Riang, Adventy Bevy Gulo. 2016. Efektivitas Pelatihan Manajemen Konflik pada Manajer Perawat Pelaksana dalam Melaksanakan Pelayanan Keperawatan di Ruang Rawat Inap Rumah Sakit Swasta Kota Medan. Universitas Sumatera Utara. Tersedia dalam: <repository.usu.ac.id> (diakses 19 Januari 2018)

Ridannti., A. (2016). Rancangan Intervensi Organizational Communiication Untuk Menurunkan Job Insecurity di PT. X. Universitas Indonesia. Tersedia dalam: <lib.ui.ac.id.> (diakses 18 Agustus 2017). 
Rigotti, T., De Cuyper, N., De Witte., H., Korek, S., \& Gisella, M. (2009). Employment Prospects Of Temporary And Permanent Workers: Associations With Well-Being And Work Related Attitudes. Journal Psychologie des Alltagshandelns / Psychology of Everyday Activity, Vol. 2 / No. 1, ISSN 1998-9970. Available from: <www.allegemeinepsychologie.info.> (diakses 21 Agustus 2017).

Riyadi, M. 2015. Hukum Kesehatan Kontemporer aegroti salus lex suprema. Malang: Akademia.

RSUD H. Badaruddin Tanjung. 2016. Profil RSUD H. Badaruddin Tanjung. Tabalong: RSUD H. Badruddin Tanjung.

Siregar, S. 2013. Metode Penelitian Kuantitatif. Jakarta: Prenadamedia Group.

Suciati., Indah. 2013. Peran Carrer Specific Parenting Behavior Sebagai Moderator Pengaruh Parental Job Insecurity Terhadap Carrer Decision Self-Efficacy. Universitas Indonesia. Tersedia dalam: <lib.ui.ac.id.> (diakses 18 Agustus 2017).

Sudibyo, Awan. 2006. Penyusunan Formula Pembagian Jasa Perawat Berdasarkan Performance Related Pay di RSUD Dr. Haryato Lumajang. Universitas Airlangga. Tersedia dalam < journal.unair.ac.id> (diakses 15 Januari 2018).

Sugiyono. 2011. Statistika untuk Penelitian. Bandung: Alfabeta.

Sugiyono. 2016. Metode Penelitian Kuantitatif, Kualitatf, dan R\&D. Bandung: Alfabeta.

Suherman, Uman. 2008. Konseling Karir Sepanjang Rentang Kehidupan. Bandung: Sekolah Pascasarjana Universitas Pendidikan Indonesia. Tersedia dalam <repository.upi.edu> (diakses 20 November 2017)

Sulistyawati, R., Nurtjahjanti, H., \& Prihatsanti, U. 2012. The Relationship Between Work Efficacy Withjob Insecurity On Procution Employeespt “ $X$ ” Semarang. Jurnal Psikologi Volume 1. Semarang: Universitas Diponegoro. Tersedia dalam <http://ejournals1.undip.ac.id/index.php/empati.> (diakses 21 Agustus 2017).

Suroto. 2000. Strategi Pembangunan dan Perencanaan Kesempatan Kerja. Yogyakarta: Universitas Gajah Mada

Sverke, M., Hellgren, J., \& Naswal, K. 2006. Job Insecurity A Literatur Review. Available from: <citeseerx.ist.psu.edu>. (diakses 1 September 2017).

Triska., F. 2013. Hubungan Antara Job Insecurity Dan Komitmen Organisasi Pada Guru Honnorer Sekolah Dasar Negeri di Depok. Universitas Indonesia. Tersedia dalam: <lib.ui.ac.id.> (diakses 18 Agustus 2017).

Widiyanto, M.A. 2013. Statistika Terapan. Jakarta: Elek Media Komputindo.

Yulrika Estelita. 2005. Sumbangan Job Insecurity dan Iklim Psikologis Terhadap Kepuasan Kerja (Kajian pada Karyawan Kontrak). Universitas Indonesia Tersedia dalam: <lib.ui.ac.id.> (diakses 18 Agustus 2017). 
Undang-Undang Republik Indonesia Nomor 1 Tahun 1974 Tentang Perkawinan. Tersedia di <www.repo.unand.ac.id/2798/1/1974> (diakses 18 Januari 2018).

Undang-Undang Republik Indonesia Nomor 44 Tahun 2009 Tentang Rumah Sakit. Tersedia di $<$ www.depkes.go.id> (diakses 18 November 2017).

Undang-Undang Republik Indonesia Nomor 13 Tahun 2013 Tentang Ketenagakerjaan. Tersedia di $<$ www.kemenperin.go.id > (diakses 18 November 2017).

Undang-Undang Republik Indonesia Nomor 5 Tahun 2014 Tentang Aparatur Sipil Negara. Tersedia di <https://luk.staff.ugm.ac.id> (diakses 18 November 2017).

Undang-Undang Republik Indonesia Nomor 36 Tahun 2014 Tentang Tenaga Kesehatan. Tersedia di <https://hukor.kemenkes.go.id> (diakses 18 November 2017).

Undang-Undang Republik Indonesia Nomor 38 Tahun 2014 Tentang Keperawatan. Tersedia di <https://kemenkopmk.go.id> (diakses 18 November 2017).

Peraturan Bupati Tapin Nomor 31 Tahun 2008 Tentang Uraian Tugas Unsur-Unsur Organisasi Rumah Sakit Daerah Datu Sanggul Rantau Kabupaten Tapin. Tersedia dalam <https://tapinkab.go.id/> (diakses 18 Januari 2018).

*Yuhansyah.

**Prof. Dr. Yati Afiyanti, SKp., MN. Dosen Universitas Indonesia Jakarta

***Dr. Machli Riyadi, S.H., M.. Wakil Direktur Administrasi dan Keuangan RSJD Sambang Lihum 